\title{
Symbolic Meaning of Batak Simalungun Wedding Ceremony in Sindar Raya Village (A Semiotic Study)
}

\section{Junifer Siregar ${ }^{1}$, Nanda Saputra $^{2}$, Eva Pratiwi Pane ${ }^{3}$}

1,3Universitas HKBP Nommensen Pematangsiantar, Indonesia

${ }^{2}$ Sekolah Tinggi Ilmu Tarbiyah Al-Hilal Sigli, Indonesia

Email: junifersiregar08480@gmail.com, Nandasaputra680@gmail.com, evapratiwi2607@gmail.com

\section{Abstract:}

This research describes the meaning of symbols, symbols, or signs contained in the Batak Simalungun wedding ceremony as a semiotic study. Symbols, symbols, or signs can be identified the meaning, use and benefits in the implementation of marriage customs for the Batak Simalungun community which need to be preserved as one of the local wisdom. The meaning of symbols, symbols, or signs is part of the semiotic approach which is the binding factor in his studies. The sign aims to simplify thoughts or ideas to facilitate communication which contains meaning, values, norms, or certain intentions that must be obeyed by the Simalungun Batak community, especially in the Sindarraya area. The signs found in the Simalungun Batak wedding ceremony are mangalo-alo boru na bayu, boras tenger, tondong welcome (mangalo-alo tondong), tombuan na marappang-appang, ambanganni tondong na baru, groceries, jambar, partadingan manurdukhon, tobus huning, panruttuki, uluni omas / tintin marakkup, suhuni appang, padaskon hiou holong, hiou parsimatuaon and panukkunan dishes.

Keywords:

symbolic; sindar raya; semiotic

\section{Introduction}

Simalungun is one of the indigenous Batak tribes who inhabit the area of North Sumatra, precisely in the east of Lake Toba (Simalungun Regency). Simalungun which has the root word "lungun" has the meaning "lonely". The name was given by outsiders because the population is very sparse and the place is very far from one another. As one of the tribes, the Simalungun Batak has a unique culture compared to other tribes in the North Sumatra area.

Tradition is something that is passed down from the heritage of the ancestors to the next generation in a relay descends performed by the indigenous communities that have become deeply entrenched the culture in life. Customs and traditions include the creation and work of human beings who have become convictions in regulating the social order of life (Pane et al, 2020).

One of the uniqueness of this culture can be seen in traditional wedding ceremonies. The formation of the Simalungun Batak marriage customs is an agreement and becomes a social bond in forming togetherness and brotherhood. The traditional wedding ceremony of the Simalungun Batak community is a series of ceremonies that exude the greatness of an order of social life for the Batak Simalungun people from generation to generation. 


\section{Linglit Journal: Scientific Journal of Linguistics and Literature \\ ISSN: 2774-4523 (Online), 2774-4515 (Print) \\ Vol. 2, No. 1, March 2021, Page: 33-47 \\ Email: linglitjournal@gmail.com}

Saragih, (2014: 94) states, "At the wedding ceremony the Simalungun Batak community displays certain behaviors in the form of objects, symbols or symbols that have meaning. such as reeds (bamboo), bulung or galuh (banana leaves), balbahul (baskets), tapongan (baskets of rattan or bamboo skin), hiou saholat, dayok binatur (neatly arranged chicken), hiou tanda hela (sarong), gotong (headband), bulang (head covering), hiou ragi pane, hiou tapak catur, suri-suri, gori, jambar (juhut), demban (betel), boras tenger (rice), omas (turmeric), hapas (cotton), timbahou (tobacco), pining (areca nut), money, bonang manalu, pinggan jarojak / pahar, nitak, and bagot.

In order to understand clearly, the meaning of the symbols contained in the traditional Simalungun Batak wedding ceremony and can be preserved as local wisdom to the younger generation of the Simalungun Batak community, the symbols, symbols or signs can be studied with a semiotic review.

\section{Review of Literatures}

\subsection{Simalungun Cultural Philosophy}

Based on the results of the Simalungun cultural seminar, it was determined that the Simalungun culture was based on "Habonaron Do Bona" which means that "Truth is the base". This term becomes the motto symbol of Simalungun Regency. "Likewise, the motto "Sapanganbei Manoktok Hitei" which means "Together". To build bridges or work together, work together to build" is used as the motto symbol of the city of Pematangsiantar. The Simalungun cultural philosophy is reflected in the Simalungun custom, namely "Tolu Sabundulan, Lima Saodorans." Tolu sabundulan has the meaning of "three at one place" which means (1) Sanina (siblings of the same family); (2) Tondong (party or group giving girls); (3) Boru (girl receiving party)

\subsection{Batak Simalungun Traditional Wedding Ceremony}

Alwi (2007: 1250) states, "The marriage ceremony is a marriage regulation that is really carried out in accordance with the ideals of a happy married life and consists of cultural values, norms, laws, and rules from one another." In traditional societies, because there are no written regulations, customs are very important. Unlike the written rules that later existed, customary rules are respected and understood without having any written sanctions either.

In the Simalungun Batak custom, the wedding ceremony is preceded by an engagement ceremony. This ceremony is of a special or autonomous nature, ending in a manner that guarantees both the beginning of the union of the two prospective brides into a new environment, as well as separation and transition from the permanent transitional period, as will be confirmed in the marriage ceremony. Thus, the marriage ceremony procedure consists of "procedures of permanent or permanent union" into a new (social) environment, and procedures of union that are personal in nature.

Saragih (2014: 20) states that, "In the traditional Batak Simalungun wedding ceremony in the Sindarraya area, there are pre-marriage to post-marriage, namely:

1. Parpadanan ni namaposo

In this parity, the bride and groom's namaposo makes a pledge to go to the level of marriage.

\section{Mambere goloman}

The prospective bride and groom inform their respective sons-in-law or son-in-law that they have made a promise to marriage with their lover. In this case only the two families of the male and female parties are concerned. After the Boru Jabu child (the son-in-law or son-in- 
law) agrees, the parents of the prospective bride and groom come to the bride-to-be's house to provide a handle in the form of a ring or money that forms a promise to the bride.

\section{Horja paima parumah}

About three days before the parumah parsahapan, (proposed), the task of the prospective groom is the son of the prospective groom, namely the son of boru jabu (son-in-law or sonin-law) the prospective groom comes to the house of the son-in-law of the candidate The bride brings pangkomabri rice (one cooked chicken that is neatly arranged) with the aim of asking for advice, what needs to be prepared to bring to the tondong house (parents of the mother or wife) and teach what to talk about to the tondong. Usually when meeting Samon the groom arrives at the house of the prospective bride and brings a tombuan (baskets of bamboo skin), bagot (water of sap), gulai panrampabi (meat), demban (betel leaf).

\section{Parumah}

In this pajabu parsahapan the groom-to-be comes to the house of the prospective bride with the aim to talk about partadingan (dowry) and what the bride-to-be has agreed upon before. The prospective groom brings a tombuan. and the bridesmaids to be handed over to the prospective bride. After that, the parents of the prospective bride hand over the tombuan to the son of Boru Jabu (son-in-law or son-in-law). After the meal, the mambere demban salpu mangan (giving betel leaf after eating) is continued, which is made in a dish that will be given to the son of the boru jabu (son-in-law or son-in-law) to the parents of the prospective bride and tondong (the party of the person parents of the mother / wife).

\section{Manggong}

Four days before the bride-to-be proposed at the bride's parents' house, the groom informs the bride's parents not to go anywhere on the appointed day. The prospective groom brings Nasi Panggong, in addition to that, the groom also provides tombuan, cooked chicken and rice to be handed over to the bride.

\section{Horja paima maralop}

a. Parboru (the bride) and the bride-to-be ask permission from the old father (our father's brother), Tulang (uncle), bapak tongah (father's youngest brother) bapak anggi (father's youngest brother) and the appropriate family according to parents.

b. Paranak (the groom-to-be). The groom's family comes together to discuss costs. Not because they are rich or poor, but to show that the family is one unit and one money. Next, print out the invitation letter, invite the group to join the maralop (propose to the bride)

\section{Mamboban indahan paralop (mangalop boru)}

For the people of Simalungun, the peak event of the wedding tradition is maralop (picking up the bride), because traditionally the bride and groom are legally the son-in-law of the male party. The task of the son of Boru Jabu (the son-in-law) is to deliver food in the form of tombuan, vegetables, rice, complete betel leaf, bagot (juice water), and money. Likewise, the son of Boru Jabu (the son-in-law or in-laws) reminded the parents of the prospective bride to provide two chickens and cooked vegetables.

\section{Party event}

a. The committee checks all the tasks that have been previously assigned.

b. Decorate the bride and groom, wearing traditional traditional clothes, complete with gotong (headband) and bulang (head covering) 
c. The meal

Before eating, the son of Boru Jabu is in charge of providing food which is called by giving banggal food (in which there are two ribs but not cut off) to hasuhuton (parents of the bride), tondong jabu (parents-in-law or parents of wife, son of boru jabu ( son-in-law or son-in-law), tondong pamupus (mother's brother), tondong bona (grandfather's in-law), tondong ni tondong (mother-in-law of the mother's brother and sister-in-law), tondong mata ni ari ( father-in-law of his father's grandfather or father's grandfather), son of boru sanina (the father's relative or other cousin or pariban).Wrapped in a tumtuman or leaf package) given to tondong mangibut (all in-laws of siblings and in-laws rather than sons), oppung (grandparents, sanina (siblings), religious leaders, boru (sisters), and pariban.

d. Manghioui (subi ni amppang) event. After the meal, followed by the manghioui (giving ulos) to the bride and groom. The tondong wears traditional clothes to the bride, the first is giving a bela biou, and attaching a gotong (headband) to the groom, then attaching biou or traditional cloth to the bride and the bride paired with suri-suri (woven cloth used as shawl) and gotong (head covering).

\section{Paulak golaman}

In the past, after eating or after giving demban na bayu (betel leaf), the bride returned the money along with the items that the groom gave to her fiancée as a marriage promise that was received earlier at the time of mambere goloman (giving ties). The bridesmaids partner as an intermediary to return the items given to the bride to be handed over to the anak boru jabu (son-in-law or son-in-law) in front of the bride and groom.

\section{Paulak limbas}

Paulak Limbas was held eight days after the wedding ceremony. The groom and bride and their close relatives especially come to the parboru house (women's party) to prioritize respect for the tondong (girl-giver party) for the condition of the parumaen (daughter-in-law) who remains in good condition during her maiden period.

\subsection{Symbolic in Simalungun Batak Marriage}

The marriage system of the Simalungun Batak community is inseparable from the philosophy of tolu sahundulan, the five saodorans. The literal meaning of the word tolu sahundulan is "three at one place" which is a symbol, if associated with the Batak social system which has three in one place, namely, Tondong, namely the party or group giving girls, Sanina is a party or group who is the same surname as someone, and Boru, namely parties or groups taking girls. These three supports play an important role in the implementation of the traditional wedding ceremony of the Batak Simalungun community (Purba, et al., 2011: 37).

The connection between the Simalungun Batak wedding ceremony and the symbolic is the symbolic communication process that occurs at the traditional Batak Simalungun wedding ceremony which is conveyed through signs or symbols namely reeds (bamboo), bulung / galub (banana leaves), balbahul (baskets), tapongan (baskets of rattan or bamboo skin), hiou sabolat, dayok binatur (neatly arranged chicken), biou tanda bela (sarong), gotong (headband), bulang (head covering), hiou ragi pane, hiou tapak catur, jambar (juhut), demban ( betel), boras tenger (rice), omas (turmeric), hapas (cotton), timbahoui (tobacco), pining (areca nut), boning manalu, pinggan. All of these symbols involve elements of a communicator with a communicant in the implementation of the Simalungun Batak traditional wedding. 


\subsection{Definition of Semiotics}

Semiotics or semiology is the science that studies systematically about signs, symbols, and the process of creation involving literary works as a figure who has his own system (http://victoryasaragih.blogspot.co.id/2014/11/analis-semiotik-pada-novel-pulang_18.html). Saussure (1857: 13) stated, "Every linguistic sign or language sign consists of two components, namely the semiotic component of communication and the semiotic component of significance. Communication semiotics emphasizes the theory of sign production, one of which assumes the existence of six factors in the communication of the sender, the receiver of the code (the sign system), the message, the communication channel, and the reference (the thing being discussed), while the semiotics of significance is what emphasizes the sign theory and understanding in a particular context.

\section{Research Methods}

This research is a type of research des- qualitative descriptive. Qualitative research is research that intends to understand the phenomena experienced by research subjects, for example behavior, perception, motivation, action. Holistically and by description in the form of words and language, in a specific natural context and by utilizing various natural methods (Moleong, 2017: 6). This research method uses a qualitative descriptive method. Descriptive method is used to describe the state of the object that is the center of attention and supports the object of research. The descriptive method is accompanied by analysis activities in order to obtain a deeper discussion of the symbolic, symbols in the Simalungun Batak traditional wedding ceremony from the semiotic study. The focus of this research is on every Simalungun Batak wedding ceremony. Data collection techniques in this study are library techniques, listening techniques and note taking techniques. Literature techniques are the sources used in research in the form of articles, books, and non-numeric data. The observation technique is to read the entire object to be studied carefully and repeatedly. Then the note-taking technique is to note things related to research.

\section{Results and Discussion}

Simalungun Batak traditional ceremony which is studied from a semiotic perspective. The order of the Simalungun Batak party alop dear located in the Sindarraya area, Durian Banggal village, Raya Kahean sub-district according to the data are as follows:

\begin{tabular}{|c|c|c|}
\hline \multirow[t]{2}{*}{ No. } & \multicolumn{2}{|r|}{ Aspects Observed } \\
\hline & Symbolic or Coat of Arms & Meaning of Signs in Semiotic Studies \\
\hline 1 & $\begin{array}{l}\text { Symbol } \\
\text { Gotong } \\
\text { Bulang } \\
\text { Tombuan } \\
\text { Pinggan panukkuan } \\
\text { Goldfish } \\
\text { Dayok Binatur } \\
\text { Hiou tanda hela } \\
\text { Hiou Pangusei } \\
\text { Hiou Holong } \\
\text { Hiou simatua }\end{array}$ & $\begin{array}{l}\text { The meaning of the sign of ethics and politeness } \\
\text { The meaning of the sign of ethics and politeness } \\
\text { The meaning of social signs } \\
\text { The meaning of the sign of supplication and hope } \\
\text { The meaning of the sign of fertility / heredity } \\
\text { The meaning of the sign of fertility / heredity } \\
\text { The meaning of the sign of ethics and politeness } \\
\text { The meaning of the sign of ethics and politeness } \\
\text { The meaning of the sign of supplication and hope } \\
\text { The meaning of the sign of supplication and hope }\end{array}$ \\
\hline
\end{tabular}




\begin{tabular}{|c|l|l|}
\hline 2. & Sign & The meaning of social signs \\
& Gambir & The meaning of social signs \\
& Pinang & The meaning of the sign of supplication and hope \\
& Mangalo-alo boru na bayu & The meaning of the sign of blessing \\
Boras Tenger & The meaning of social signs \\
Ambangan & The meaning of the sign of communication \\
Panganan & The meaning of the sign of fertility \\
Jambar & The meaning of social signs \\
Partadingan manurdukhon & The meaning of social signs \\
Tobus buning & The meaning of a sign of greatness and honor \\
Panruttuki & The meaning of a sign of greatness and honor \\
Uluni omas / Tintin marakkup & The meaning of a sign of greatness and honor \\
& Subini appang / parbioun & The meaning of the sign of ethics and politeness \\
Paulak limbas & The meaning of the sign of ethics and politeness \\
\hline
\end{tabular}

4.1 The Meaning of the Communication Sign at the Simalungun Batak Wedding Ceremony

The meaning of communication signs in the Simalungun Batak wedding ceremony can be seen in the following signs:

\section{a. Ambangan Tondong Na Baru}

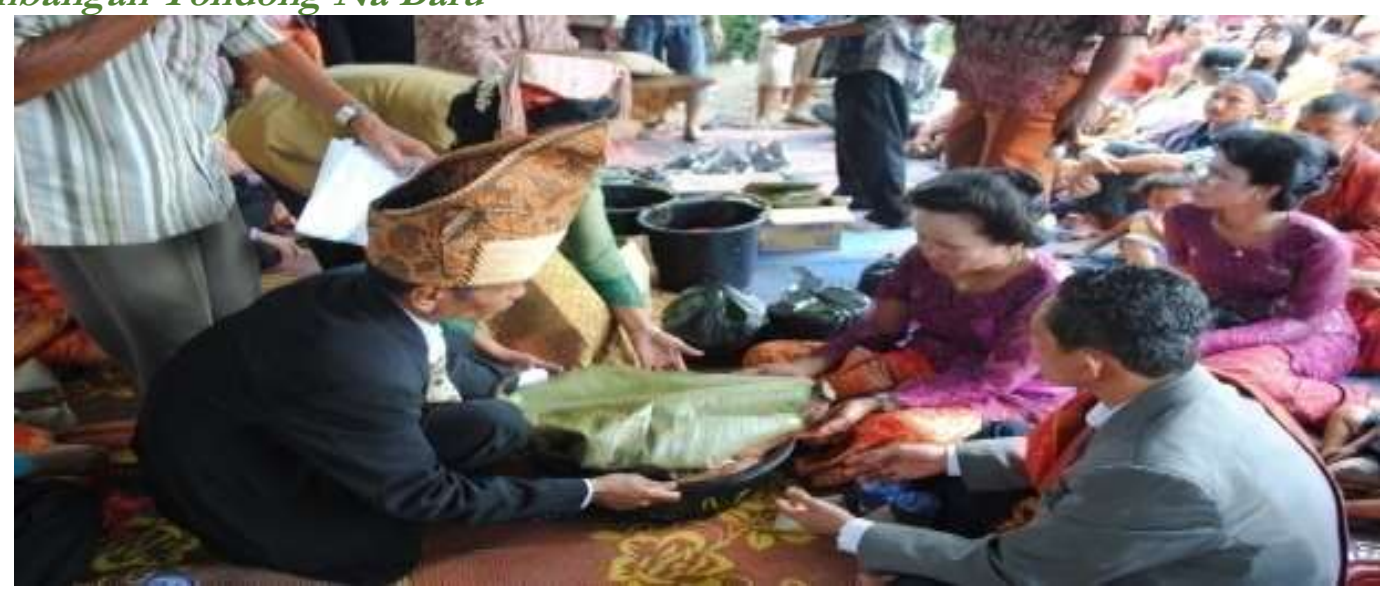

The handing over of the traditional sign food (mbangan tondong na baru) is done by a party representing the two families of the bride and groom. The man and his wife were given a sign of food accompanied by other relatives being guided parbata king (customary head) is handed over to the woman in the traditional language which means showing humility by saying, even though the food brought is small or perfunctory, it can bring physical and spiritual benefits from the parboru (women's side) tondong and all who eat it, while said the words "bani nasiam tondong nami, on dassa naboi tarbahen banami nasongon tudub-tudub ni sipanganon bubani nasiam tondong nami, in ma malas uhur nasiam, ase riap mangan ma hita ganup".

\subsection{The Meaning of Social Signs in the Batak Simalungun Wedding Ceremony}

The sign in the Batak Simalungun wedding ceremony is a social identity in the kinship and the Batak Simalungun community. The meaning of social signs in the Batak Simalungun wedding ceremony is as follows: 

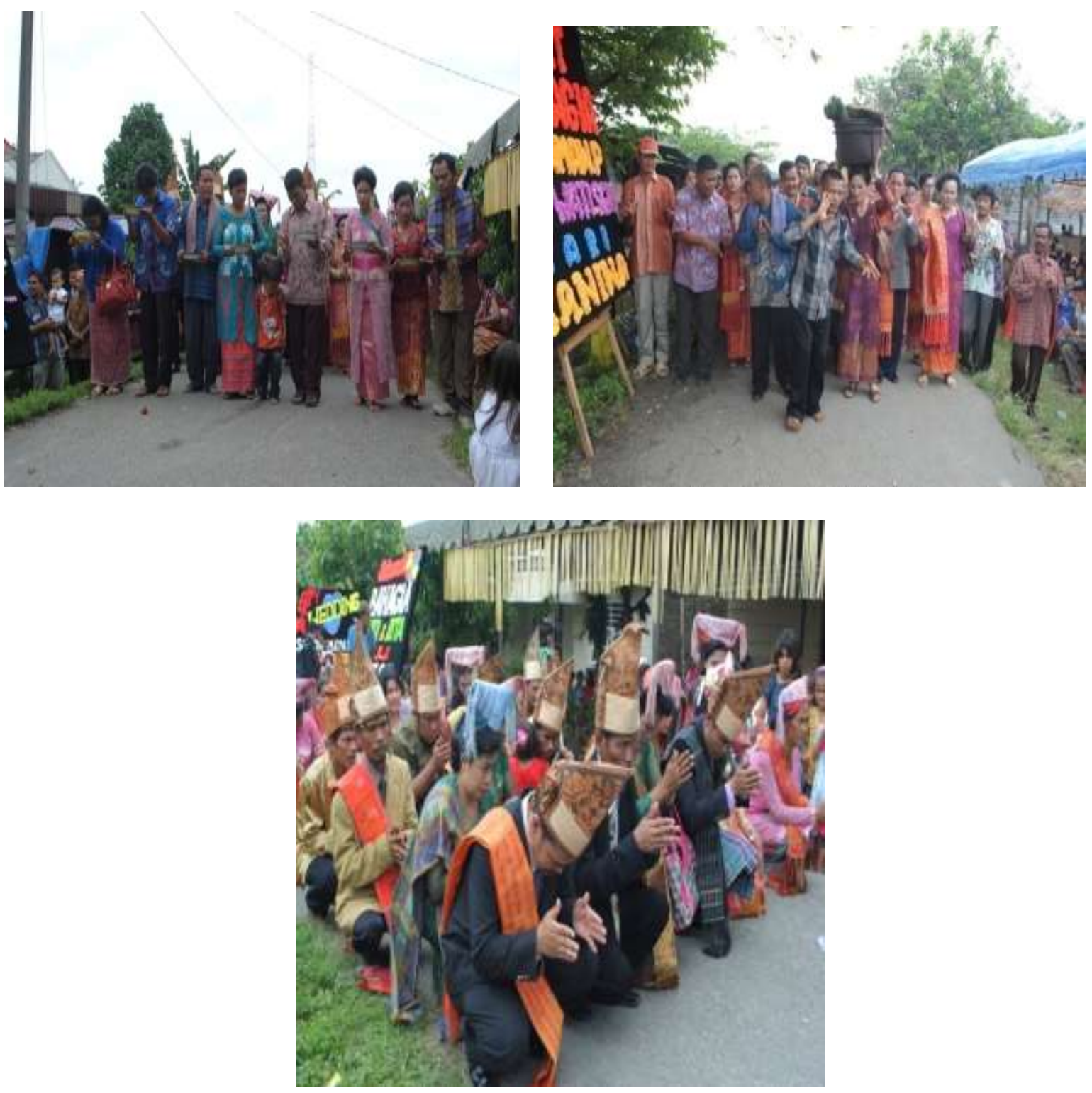

Party paranak come to worship or pay homage to the parboru three times by notifying him that the customary horja has been carried out. Then the paranak came to give demban vegetables made in plates or dishes containing money (Batu demban), betel leaves and tobacco by bowing their heads while managing to the parboru and their entourage. Furthermore, the paranak led the bride to the house that she was legally a family (martondong maranak boru tondong bubagas rumah).

During this mangalo-alo tondong, the bride brings rice and tombuan along with the contents which are handed over to the son of the bride and groom. These tombuans can be in the form of reeds (bamboo), bulung galuh (banana leaves), balbabul (baskets), pinolang-nolang handkerchiefs, tapongan, ampangni bambing, biou sabolat, bonang manalu, dayok regulating manggoluh, beautiful boras sipusuk and apuran. Below is explained the meaning of rice and tombuan, namely; The meaning of the sign of rice means very strong or hard grain, so that the bride and groom have a good livelihood and remain strong in building their household and become a helper and hope for the people around them. Furthermore, the meaning of the sign of the tombuan, namely; reed 
(bamboo) its meaning is useful as a ladder, boru (tolu sabundulan) of one heart and one mind in doing the work being carried out, dayok regulate manggoluh means that like a arranged chicken, the order of the household is good both in the family and in society, beautiful boras sipusuk means to be healthy, happy and not lacking in anything, the meaning is no matter how difficult the situation is, if it is done it will produce good results The social meaning of the sign of the vegetable demban on the plate / dish in the form of money, betel leaf and tobacco, namely; plate or dish means a means or symbol for starting a traditional conversation. Tobacco means remembering and betel leaf means starting and closing a conversation or what is often called the arrogant tip. The betel leaf means that with a sincere heart without lies and pretense. Dayok set manggoluh means that like the arranged chicken, the order of the household both in the family and in the community, beautiful boras sipusuk means to be healthy, happy and not lacking in anything, the meaningful effect is no matter how difficult the situation is, if it is done it will produce good results. The social meaning of the sign of the demban sayur on the plate / dish in the form of money, betel leaf and tobacco, namely; plate or dish means a means or symbol for starting a traditional conversation.

\section{b. Jambar}

Jambar has the meaning of telling you that the custom is valid and asking for a blessing. The division of the jambar is made right in front of the aisle. Parjambaran na mardalan or part of the meat that goes in the form of:

1. Borgok (neck) given to tondong bona (grandfather's father-in-law)

2. Ulu (pig's head) given to tondong pamupus (mother's brother)

3. Tulan bolon (hamstrings) given to tondong jabu (parents-in-law or person of wife)

4. Huang-huang (groin) given tondong ni tondong (mother-in-law from mother's brother and sisterin-law)

5. Ihur (tail) is given to tondong mangibut (all parents-in-law of siblings or son-in-law)

6. Tulan tangan (part of the foreleg) given to sanina (sibling)

7. Tulan parnamur (the meat between the thighs and the claws) is given to the Anak Boru Jabu (the son-in-law)

8. Popat (groin) given to boru (daughter)

\section{c. Munurdukhon Partadingan (Fulfilling the Dowry Money)}

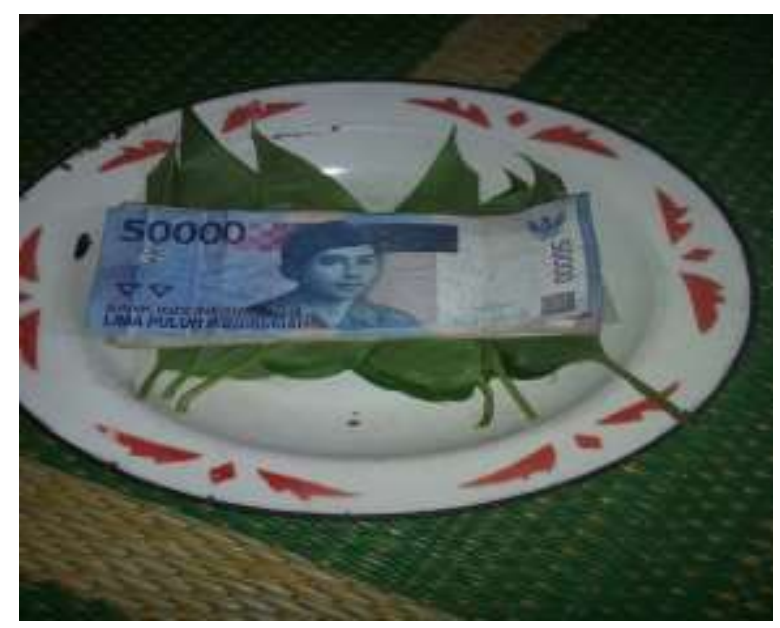

The parents of the groom and the bride and groom come to the parents of the bride to deliver partadingan (dowry of marriage). Previously the bride and groom gave a pair of betel to the parents of the bride. 
Inside this partadingan manurdukhon there are boras (rice), timbahou sapangpang, demban sagunringan (sirih), boning manalu (thread), omas (turmeric) Boras (rice) means a very strong and hard grain is a tool to bless the souls of the bride and groom so that they are calm and strong in building their homes and become helpers and hopes for the people around them. Timbahou sapangpang means to remember. Demban sagunringan means tied, neatly arranged with a total of six pairs of one tie. Bonang Manalu means a binder for tondong, sanina, boru (tolu sabundulan). Omas (turmeric) means the most valuable item means gold which shows our compassion.

\section{d. Tobus huning (substitute for tired)}
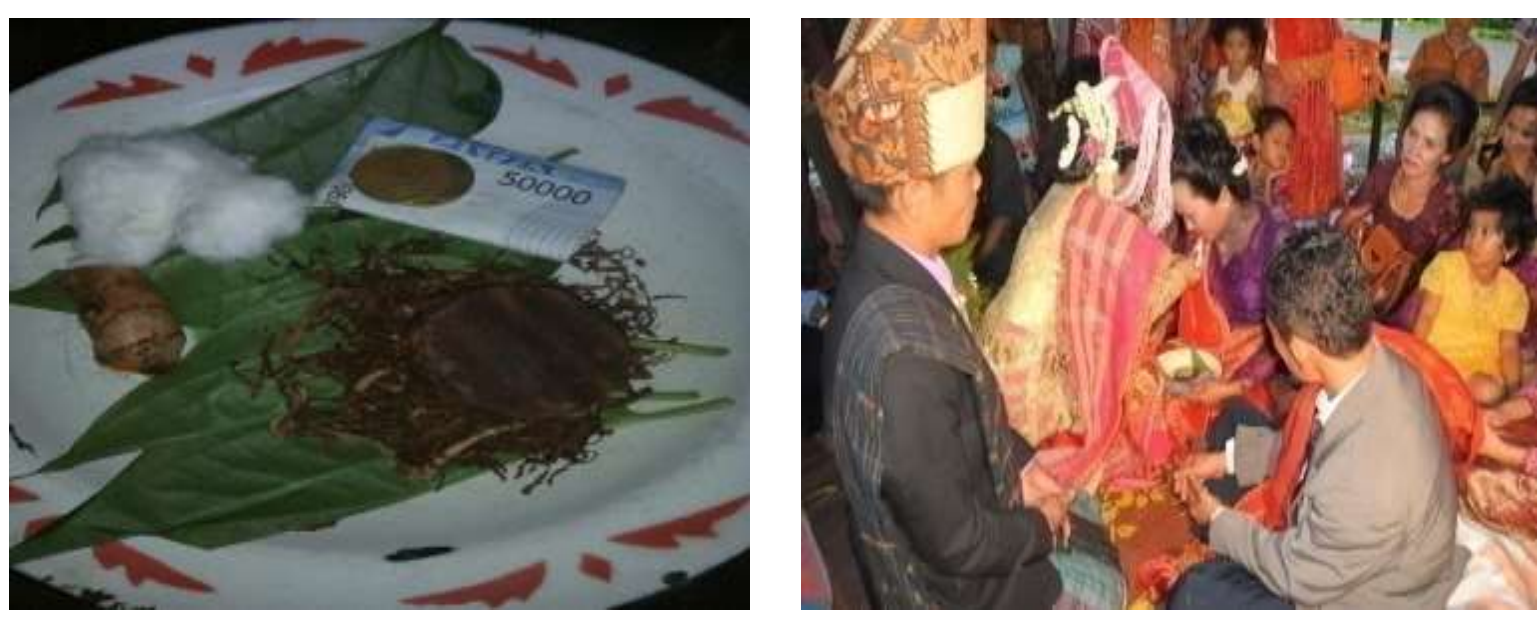

The bride and groom come to the bride's parents to give tobus huning (substitute tired of raising daughters). Inside the yellow tobus plate contains buning (turmeric) which means the most valuable item, meaning gold, which shows our compassion. The Hapas (flower) is white and clean, the meaning is sincere, and the family gives with respect. Demban (sirih) means starting and closing a customary conversation or often called the tip of arrogance (money or food served as a symbol of submission to worship, respect. Timbahou (tobacco) means remembering. Gambir means tenacious, Pinang means straight (open heart).

\section{e. Tombuan na marappang-appang}

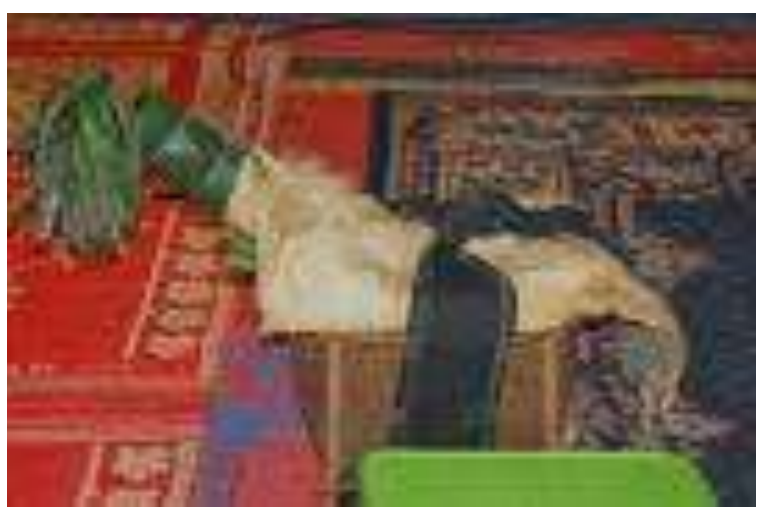

Tombuan means baskets made of bamboo skin containing chicken meat broiled in bamboo, rice and chicken meat in a basket and covered with goat skin. This tombuan is used during pajabu parsahapan and at the manobu pesta ni boru. Usually the paranake (groom) brings the tombuan during the pajabu parsahapan (discussing the dowry) to the parboru (women's side) house which contains a chicken that has been cremated in bamboo, some of which is cooked in the 
priuk after which it is transferred to the basket, rice, meat, rice in the basket. After that it is put into a tapongan (basket made of rattan). Furthermore, the tombuan used at this manohu ni boru party was carried by the tondong. Below is explained the meaning of the tombuan, namely; reed (bamboo) its meaning is useful as a ladder.

4.3 The Meaning of the Signs of Request and Hope in the Simalungun Batak Wedding Ceremony

The meaning of the signs of request and hope can be seen as follows:

a. Mangalo-alo boru nabayu
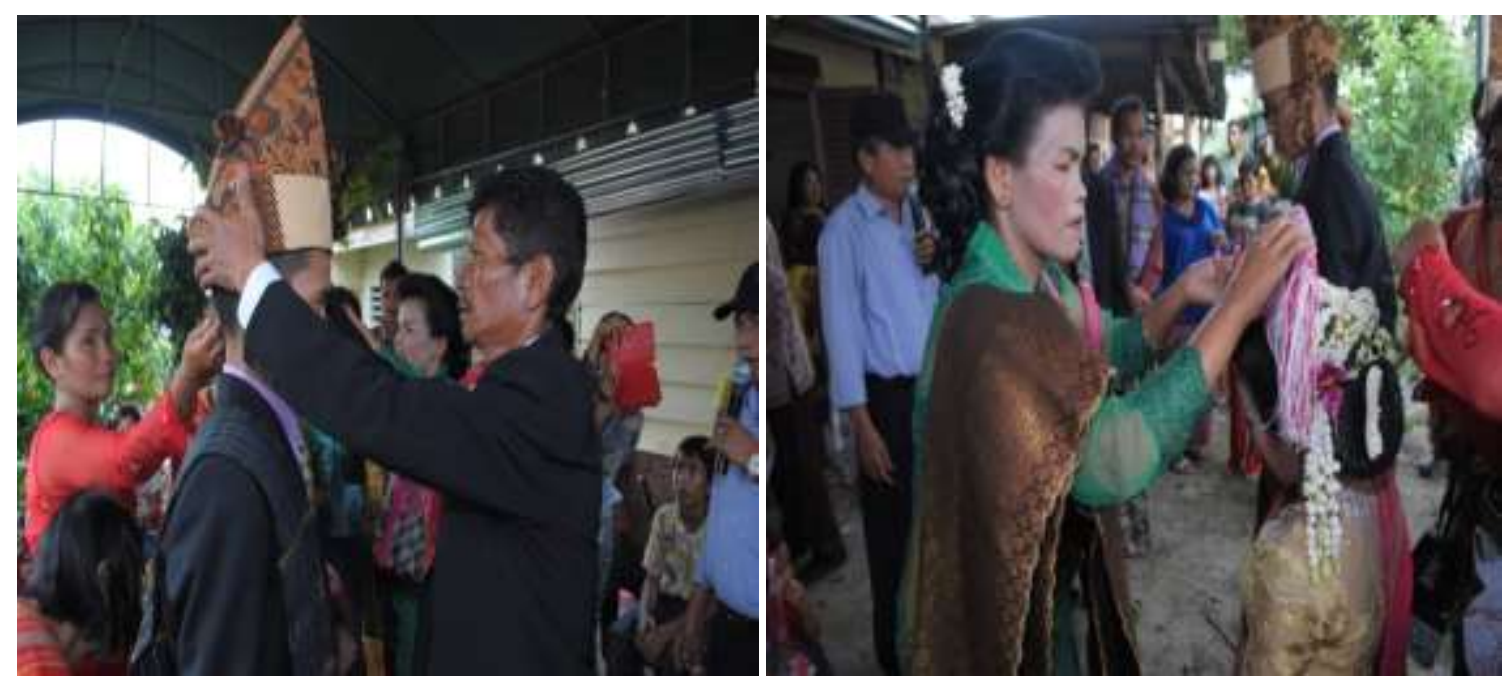

At this stage the bride and groom are greeted and presented with betel leaves and dressed in traditional Simalungun clothes. Furthermore, the Anak Boru Jabu leads the two brides into the house using a long cloth and leads them to the aisle.Then the groom's parents point out Boras Tenger, which means that the bride brings thanks to the house, traditional clothing means that the bride and groom are legally husband and wife in terms of Simalungun customs. The long cloth means to quickly get offspring.

\section{b. Hiou parsimatuaon}
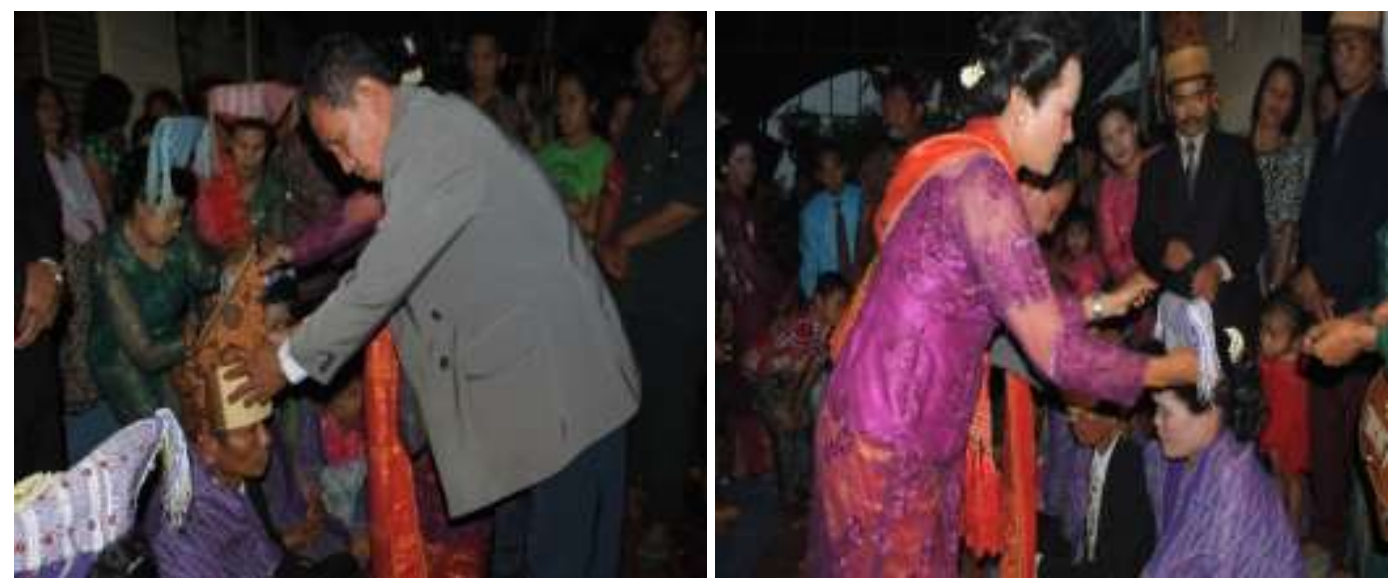

The meaning of bulang and gotong assistance is given to the bride-in-law to be healthy in guiding her parmaen (son-in-law). 


\section{c. Pinggann Panukkunan}

Pinggan panukkeunan (plate) which contains boras (rice), demban (betel) and ringgit (money). Pinggan (plate) with its meaning is a means or symbol to start a traditional conversation. Boras (rice) means a tool to bless the spirits and souls of the bride and groom so that they remain strong in building their household and become a helper and hope for the people around them. The strength of the rice seeds is the hope and source of life for many people.

Demban (betel) is an object which contains a sacred meaning. Demban means that with a sincere heart without lies and pretense. In the traditional Batak Simalungun wedding ceremony, when it is delivered to the parents of the bride, ringgit / duit (money) is placed on a plate along with rice and demban (sirib). By giving ringgi (money) depends on the agreement of both parties. The bride (parboru) is already part of the family of the groom (paranak). Ringgit / money(money) shows the cause and effect that occurs between the two sides of the family so that the Simalungun Batak wedding ceremony is carried out.

\subsection{The Meaning of Ethics and Courtesy in the Simalungun Batak Wedding Ceremony} The meaning of ethics and politeness can be seen as follows:

\section{a. Suhini Appang / Parhiouon}
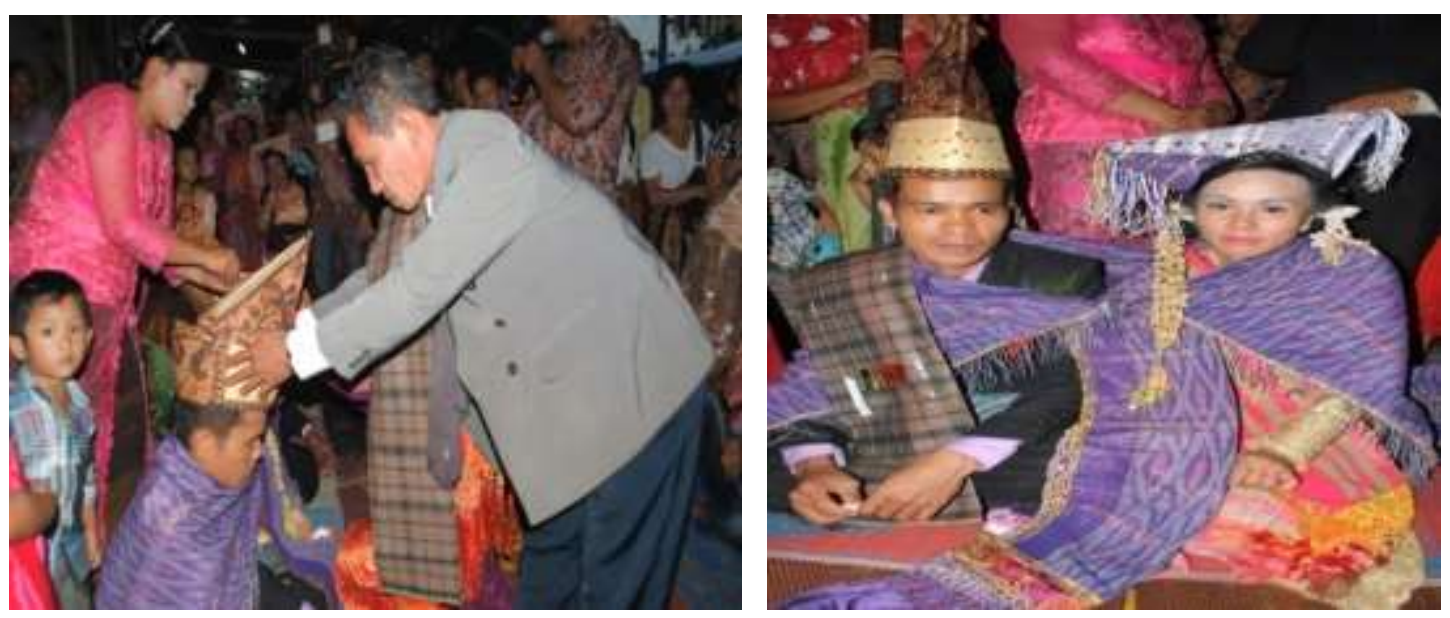

\section{Gotong and Bulang}

Gotong and Bulang given by the parents of the bride to the bride and groom as a sign of bolong (love) that they are legally husband and wife.

\section{Hiou Pangusei}

Hiou Pangusei is a traditional Simalungun biou. This type of bion pangusei is like biou ragi panei, biou tapak catur (bion na marambu). The biou which is usually used in the traditional Batak Simalungun marriage is biou tapak catur (biou na marambu).

\section{Hiou tanda bela}

Hiou tanda bela what is given to the groom is the hiou of choice, of good quality and expensive. This was done because the Batak Simalungun people did not want Hela (their son-inlaw) to feel disappointed during that happy day. Hiou tanda bela are used at certain times during traditional events to serve tondong. The hiou (sarong) that is given to the groom is called biou tanda bela which means that the groom is diligent in following traditional events. 


\section{b. Padaskon Hiou Holong}

After the apppang naoppat event, the next event was the padaskon hiou holong (sign of love) which was hosted by the king parhata parboru. Those who conveyed the hiou holong were a group from the parboru (an invitation from the woman). The type of biou (cloth) given to the bride and groom is in the form of a long cloth and sarong. The meaning of hiou holong is that we hope to get a baby, cheap sustenance and a long life.

\subsection{The Meaning of Greatness and Honor in the Simalungun Batak Wedding Ceremony}

In the traditional Batak wedding ceremony, Simalungun panruttuki and padaskon tintin marakkup are signs of greatness and honor for women and men. The signs are as follows:

\section{a. Panruttuki}

The purpose of this event is to introduce the woman's family so that the man's family knows who the relatives of the woman are while giving money to those concerned. Symbolically, what is given directly to only four people is called suhini ampang na oppat (four legs of the holder / basket bearer) which is a symbol of the pillars of the traditional event.

\section{b. Uluni Omas / Titin Marakkup}

Given to the tulang (uncle) of the groom. It is the bride's parents who hand over the money from that part of the sinamot (dowry).

\section{c. Paulak Limbas}

Paulak Limbas was held eight days after the wedding ceremony. The meaning of greatness and honor is the sign of paulak limbas, which is the first visit of the bride to her in-law's house and the woman cannot come to her parents' house at will without the consent of her husband or her family.

\subsection{Meaning of Fertility in the Simalungun Batak Marriage Ceremony}
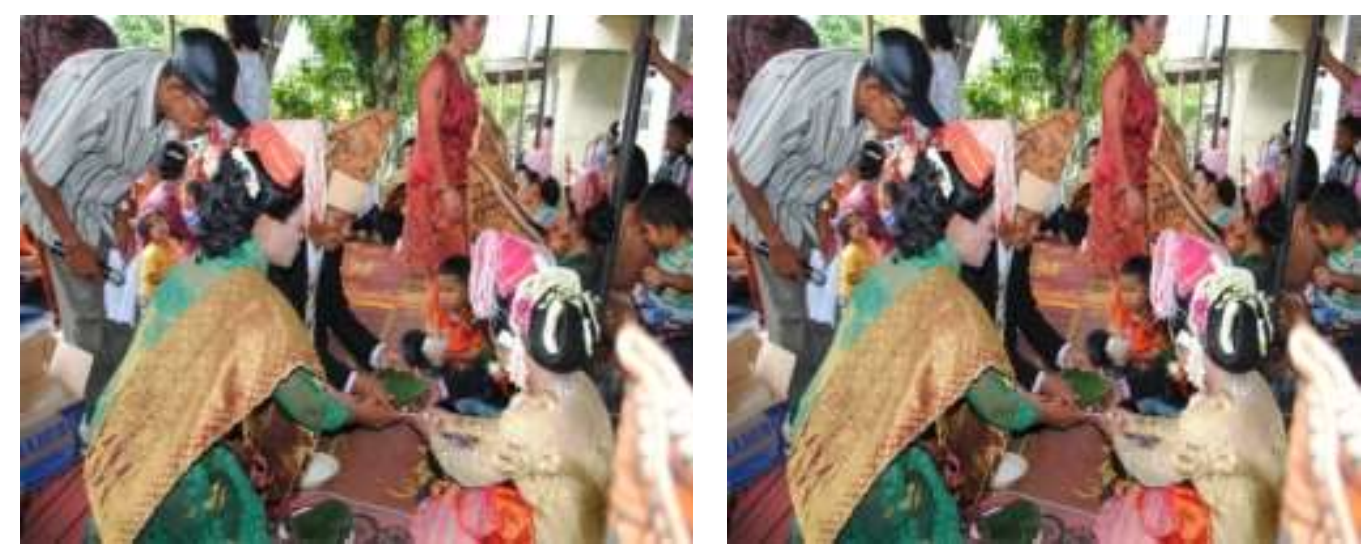

\section{a. Dapotanni Panganan Bridal}

Before the meal, the groom's parents first manurdukhon dapotanni bridal (food served to the bride and groom), which is a typical Simalungun batak food in the form of binatur dayok na with special spices mixed with blood and a type of wood sap which is often called holat. Binatur dayok has the meaning of the hope of the parents of the groom and the bones of the bride and groom so that they are of one heart and one mind in running the wheels of the household and are unanimous in all their work and efforts towards happiness and prosperity and also with their siblings, so that they do not would be swayed by anything that would get in their way. 


\section{b. Hand over the Goldfish}

This fish has the nature of living in clear water and when swimming is always side by side. The goldfish is cooked in a typical Simalungun Batak "naiarsik". This symbol means the hope for the bride and groom and her family, namely "seia sekata" together and cheap fortune. Goldfish is a symbol that depicts the couple of the bride and groom.

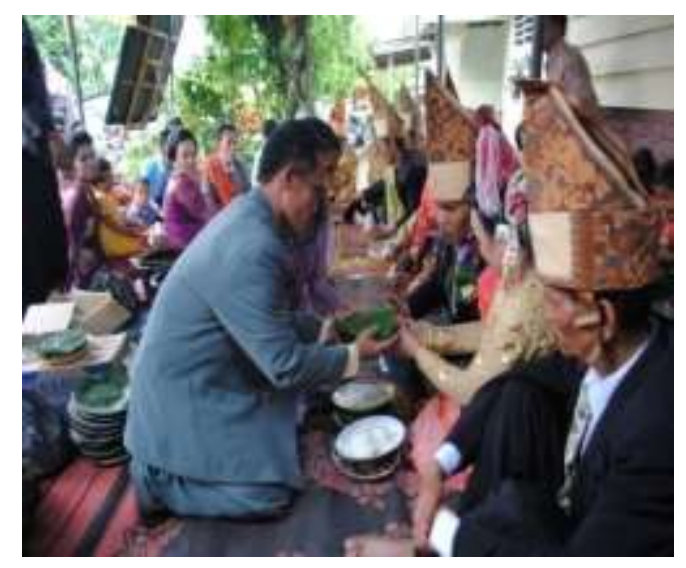

\subsection{Meaning of Blessing in Batak Simalungun Marriage Ceremony}

The meaning of blessing can be seen during the manghioui event. The tondong (groom's side) gives the biou to the woman, and then the sanina and boru give the bride (both male and female) manghioui. The meaning of this ceremony is that the bride and groom are always together in joy and sorrow.

\section{a. Boras Tenger}

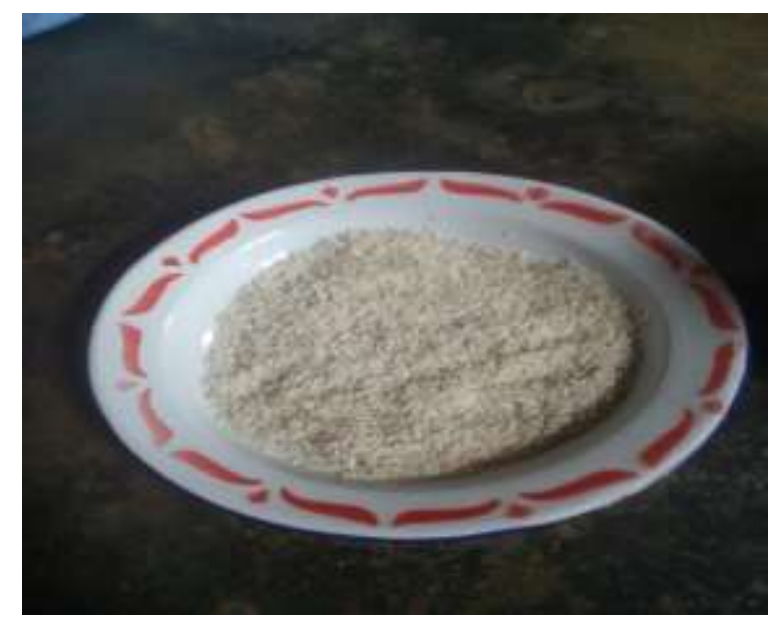

Boras Tenger the meaning is boras pejomgomi so that the bride and groom have a good livelihood. In the traditional Batak Simalungun wedding ceremony, boras (rice) is usually placed in the bahulbahul (basket). Then the rice is sprinkled on the heads of the bride and groom. By sowing the rice, their souls have been blessed and they become a blessing to all of us.

\section{Conclusion}

Cultural element that uses symbols, symbols or signs to describe the culture of the tribe, so that it can be lived from time to time which contains very broad and strong values and norms and regulates and directs the behavior of each individual in a society. This can be preserved as 
local wisdom. Based on the results of research and discussion, the authors conclude that in the Simalungun Batak traditional wedding ceremony, symbolic elements are found in the form of the symbolic symbol of Simalungun's traditional Batak marriage.

The elements related to symbolics, symbols, are as follows:

Symbol:

1. Gotong

2. Bulang

3. Tombuan

4. Pinggan panukkuna

5. Goldfish

6. Dayok Binatur

7. Hiou tanda hela

8. Hiou Pangusei

9. Hiou Holong

10. Hiou simatua

Sign:

1. Pinang

2. Mangalo-alo boru na bayu

3. Boras Tenger

4. Mangalo-alo tondong

5. Ambangan

6. Panganan

7. Jambar

8. Manurdukhon Partadingan

9. Tobus huning

10.Panruttuki

11.Uluni omas / Tintin marakkup

12.Suhini appang / parhiouon

13.Paulak Limbas

The symbolic meanings contained in the semiotic study at the Batak Simalungun wedding ceremony are:

1. The meaning of the sign of ethics and politeness

2. The meaning of social signs

3. The meaning of the sign of supplication and hope

4. The meaning of the sign of fertility / heredity

5. The meaning of the sign of ethics and politeness

6. The meaning of the sign of supplication and hope

7. The meaning of social signs

8. The meaning of the sign of blessing

9. The meaning of the sign of communication

10.The meaning of the sign of fertility

11. The meaning of a sign of greatness and honor

12.The meaning of the sign of ethics and politeness 


\section{References}

Alwi, et al. (2007). Kamus Besar Bahasa Indonesia Edisi Ketiga. Jakarta. Balai Pustaka Moleong, lexy J. (2012). Metodologi Penelitian Kualitatif. Bandung : Remaja Rosdakarya.

Pane, A. et al. (2020). The Performance of Mangupa Tradition in Angkola Custom, Medan, Indonesia. Budapest International Research and Critics Institute-Journal (BIRCI-Journal). P. 1747-1757.

Purba, Rudolf, et al. (2011). Peradaban Simalungun. Pematangsiantar : Komite Penerbit Buku Simalugun (KPBS).

Saragih, J.R. (2014). Buku Adat Ni Simalungun. Pematang Siantar: Presidium Partuha Maujana Siamalungun.

Saussure, Ferdinand. (1857). Pengantar Linguistik Umum. Universitas Gajag Mada.

Sobur, Alex. (2009). Semiotika Komunikasi. Bandung. PT. Remaja Rosdakarya

http://victoryasaragih.blogspot.co.id/2014/11/analisisis-semiotik-pada-novel-pulang_18.html 